\title{
Killing Pain
}

National Cancer Institute

\section{Source}

National Cancer Institute. Killing Pain. NCI Thesaurus. Code C101163.

A sensation of extreme discomfort and ang uish that is perceived as severe enough to cause one's death. 